Fumio Goto MD PH D, Nao Fujita MD PH D, Tatsushi Fujita MD PHD

\title{
Cerebrospinal fluid catecholamine levels and duration of spinal anaesthesia
}

The effects of carecholamines added to dibucaine on the duration of spinal anaesthesia and cerebrospinal fuid catecholamine levels were studied. Free norepinsphrine levels increased from $0.107 \mathrm{ng} \cdot \mathrm{ml}^{-1}$ before antaesthesia to $5.8 \mathrm{ng} \cdot \mathrm{ml}^{-1}$ and $1,2.38 \mathrm{ng} \cdot \mathrm{ml}^{-1}$ after $1.0 \mathrm{\mu g}$ or $100 \mu \mathrm{g}$ norepinephrine had been added to the local anaesthetic. The effects of $2.5 \mathrm{\mu g}$ of either norepinephrine or epinephrine added to dibucaine on the duration of motor blockade and sensory regression time were compared. The duration of both were significantly prolonged by added norepinephrine from $96 \pm 17 \min 10193 \pm 20 \mathrm{~min}$ (sensory blockade) and from $116 \pm 14$ min to $204 \pm 34 \mathrm{~min}$ (motor blockade), but were not changed by addition of epinephrine. These data suggest that a $2.5 \mathrm{\mu g}$ dose of norepinephrine is sufficient to prolong the duration of spinal anaesthesia and more effective than the same dose of epinephrine.

For many years vasopressors such as epinephrine (EP) and phenylephrine have been used to prolong the duration of action of various local anaesthetics following subarachnoid administration. Vasoconstrictors are believed to affect the absorption of local anaesthetics. However, animal studies have recently demonstrated that norepinephrine (NE) and phenylephrine elevate the nociceptive threshold to thermal stimuli, ${ }^{1}$ and intrathecal administration of alpha adrenergic antagonists partially antagonises the analgesia produced by micro-injection of morphine in periaqueductal gray matter or the nucleus reticularis giganto cellularis. ${ }^{2}$ Bedder et $a l .^{3}$ also reported that the alpha $a_{2}$ adrenoceptor agonist clonidine was as effective as EP in prolonging tetracaine-induced spinal anaesthesia in dogs. These

\section{Key words}

SYMPATHETIC NER VOUS SYSTEM, CATECHOLAMINES: epinephrine, norepinephrine; ANAESTHETIC TECHNIQUES: spinal.

From the Department of Anesthesiology, Gunma University Hospital, Maebashi, Gunma 371, Japan; and the Department of Anesthesia (NF), Tokyo Red Cross Hospital, Tokyo, Japan. Address correspondence to: Dr. Goto. results were characterized as a specific alpha adrenergic receptor interaction in the spinal anti-nociceptive system. ${ }^{1}$

The main catecholamine (CA) in cerebrospinal fluid (CSF) is NE, ${ }^{4}$ and NE levels in the CSF are higher in patients with chronic pain ${ }^{5}$ than in surgical patients without pain undergoing spinal anaesthesia. These data suggest that endogenous spinal NE has direct effects on the spinal nociceptive system that modulate the central transmission of pain information. However, there are few reports of $\mathrm{CA}$ analysis in CSF during spinal anaesthesia. Moreover, there are few clinical reports on the effect of added NE on spinal anaesthesia.

We attempted to determine the effects of NE in prolonging the duration of spinal anaesthesia and to measure the concentration and the type of catecholamine in CSF following the administration of CA added to dibucaine. We administered small doses of CA to prevent the side effects of spinal anaesthesia with use of vasoconstrictive drugs, as the endogenous CA levels in the CSF are very low and more than 50 per cent is of the inactive, conjugated type. On the other hand, exogenous CAs administered with local anaesthetics will be the active, free types in the CSF.

\section{Methods}

Fifty-seven adult patients without neurological disorders scheduled for hernioplasty or orthopaedic surgery of their lower extremities were selected. They were classified as American Society of Anesthesiologist's physical status class I. With approval from our Committee on Human Research, all patients were informed of the nature of the experiment and their written consent was obtained. All operations started between 09:00 and 10:00 hours. Food and fluids were withheld from 21:00 hours the previous evening. Lactated Ringer's solution was administered at $500 \mathrm{ml} \cdot \mathrm{b}^{-1}$ during the study, anaesthesia and surgery. No medication was given to any patient before or during the study period.

In Group 1 there were 27 patients (Table I); nine patients received $2 \mathrm{ml}$ of hyperbaric dubucaine $(0.3$ per cent). Of the other 18 patients (Figures 1 and 2), each one or two patients were selected and anaesthetised with 


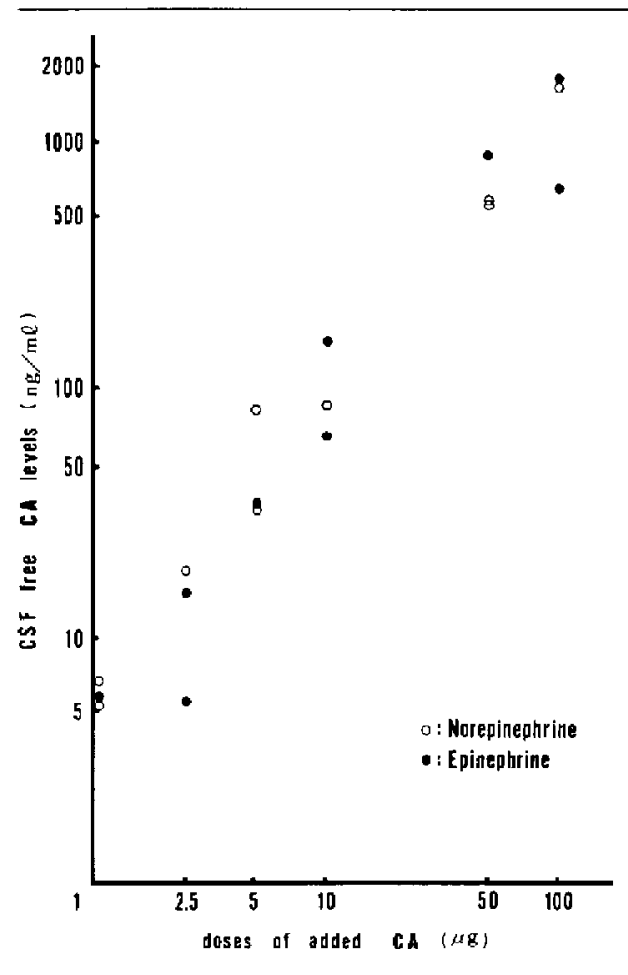

FIGURE 1 Correlationship between the doses of added catecholamine (CA) to spinal anaesthesia and the CSF free CA levels.

dibucaine with NE or EP $1.0,2.5,5.0,10.0,50.0$, or 100 $\mu \mathrm{g}$. The subjects were studied in a level, lateral position and $2 \mathrm{ml}$ of CSF were withdrawn just before and $3 \mathrm{~min}$ after the administration of the drug through a spinal needle that was inserted at the fourth lumbar interspace. Technical and ethical considerations made it impossible to take multiple sample collections at different levels of the subarachroid space.

Following CSF collection the patients were maintained

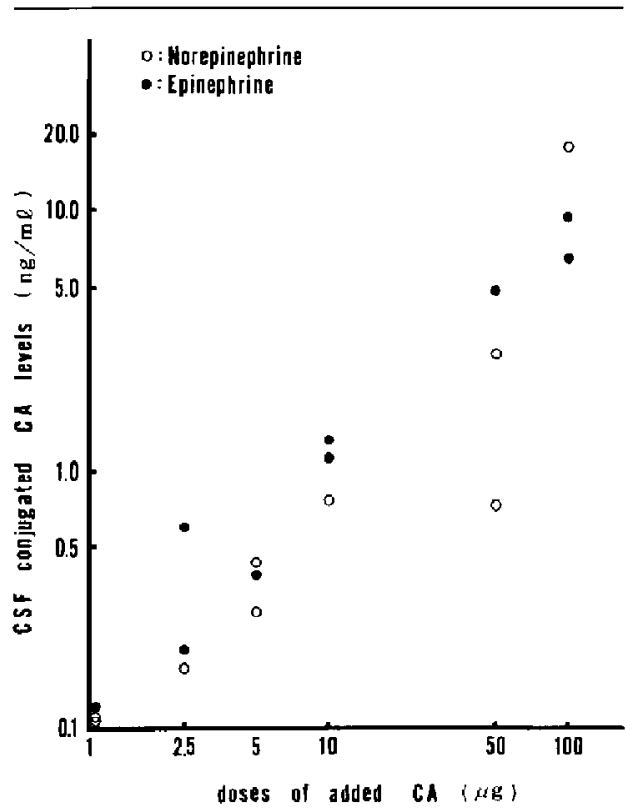

FIGURE 2 Correlationship between the doses of added catecholamine (CA) to spinal anaesthesia and the CSF conjugated CA levels.

in the supine position. CSF samples for dctermination of $\mathrm{CA}$ were collected into chilled silicon tubes and stored at $-40^{\circ} \mathrm{C}$ until the levels of $\mathrm{CA}$ were determined. $\mathrm{CA}$ was selectively isolated from the samples by activated alumina as described by Anton and Sayre's method. ${ }^{6}$ Conjugated CA was hydrolysed in boiling water with $1 \mathrm{~N} \mathrm{HCl}$ for 30 $\mathrm{min}$. The elute for $\mathrm{CA}$ was determined by reverse phase high performance liquid chromatography (Waters Associates, model 701B) with electron capture detector (Bioanalytical System).

Chromatograms were recorded on a Waters 703 Data Module set in the peak height mode. An internal standard dihydrobenzylamine $(10 \mathrm{ng})$ was included in the sample

TABLE I Patients ${ }^{\prime}$ age, body weight and highest level of spisal anaesthesia

\begin{tabular}{|c|c|c|c|c|c|}
\hline Group & $n$ & Age & $\begin{array}{l}\text { Body } \\
\text { weight }\end{array}$ & $\begin{array}{l}\text { Highes } \\
\text { level of } \\
\text { anaesthesia }\end{array}$ & Drugs \\
\hline & 9 & $45.7 \pm 4.9$ & $56.1 \pm 3.2$ & $\operatorname{Th} 7 \pm 1$ & Dibucaine alune \\
\hline $\mathbf{I}$ & $\begin{array}{l}9 \\
9\end{array}$ & $\begin{array}{l}46.3 \pm 5.7 \\
44.9 \pm 6.1\end{array}$ & $\begin{array}{l}53.2 \pm 2.9 \\
54.5 \pm 2.7\end{array}$ & $\begin{array}{l}\text { Th7 } \pm 1 \\
\text { Th6 } \pm 1\end{array}$ & $\begin{array}{l}\text { Dibucaine + EP } 1-100 \mu \mathrm{g} \\
\text { Dibucaine + NE } 1-100 \mu \mathrm{g}\end{array}$ \\
\hline 2 & 10 & $45.9 \pm 4.0$ & $51.5 \pm 1.8$ & $\operatorname{Th} 7 \pm 1$ & Dibucaine alone \\
\hline 3 & 10 & $44.4 \pm 6.8$ & $54.1 \pm 3.8$ & Th7 \pm 1 & Dibucaine + EP $2.5 \mu \mathrm{g}$ \\
\hline 4 & 10 & $47.8 \pm 5.2$ & $55.6 \pm 3.1$ & Th $6 \pm 1$ & Dihucaine + NF. $2.5 \mu \mathrm{g}$ \\
\hline
\end{tabular}


to accommodate dilution of CSF and determination of $\mathrm{CA}$ recoveries. The recovery of CA analysis was $83 \pm 4 \mathrm{pcr}$ cent. Conjugated $C A$ levels were determined from the total $C A$ value minus the free $C A$ value.

In 30 patients the effects of added $2.5 \mu \mathrm{g}$ EP or $2.5 \mu \mathrm{g}$ $\mathrm{NE}$ on the duration of anaesthesia were evaluated in Groups 3 and 4 and compared with Group 2 patients who were anaesthetised with $2 \mathrm{ml}$ plain dibucaine (Tables I and II). The randomized double-blind study was designed to measure the duration of anaesthesia for hernioplasty in Groups 2, 3 and 4. All observations were made by an independent physician not involved in the study. The added dose of CA $(2.5 \mu \mathrm{g})$ was based on preliminary studies and the results of Group 1 patients. We feit that 2.5 $\mu \mathrm{g}$ of $\mathrm{NE}$ should be enough to prolong the duration of spinal anaesthesia, from the data in Group 1.

Duration of anaesthesia was evaluated every 10 min by ice cold stimuli, until the beginning of sensory regression. A decrease in the level of temperature sensation of two dermatomes was defined as the beginning of sensory regression. Motor block was assessed by the method described by Bromage ${ }^{7}$ and determined by the recovery of knee joint movements, with ability to lift over $5 \mathrm{~cm}$. When asy mmetry in the quality of motor block existed the value for the lower leg in the lateral position for induction of spinal anaesthesia was used. Ankle and foot movement was not observed as some patients did not have complete paralysis of ankles and toes.

Patients who nceded additional drugs for complete analgesia and/or for maintaining blood pressure in the operating room were excluded from the study.

All results are expressed as means \pm SEM, unless otherwise indicated. Changes were considered significant when $\mathrm{p}<0.05$.

\section{Results}

In Group 1 there were no significant differences in preanaesthetic CSF free NE levels between patients who received plain dibucaine $\left(0.104 \pm 0.014 \mathrm{ng} \cdot \mathrm{ml}^{-1}\right)$, added EP $\left(0.110 \pm 0.033 \mathrm{ng} \cdot \mathrm{ml}^{-1}\right)$ or added NE $(0.107 \pm 0.028$ $\left.\mathrm{ng} \cdot \mathrm{ml}^{-1}\right)$. Fnee NE levels increased after the drug adminis-

TABLE II Duration of spinal anaesthesia

\begin{tabular}{lll}
\hline & $\begin{array}{l}\text { Duration } \\
\text { of sensory } \\
\text { blockade (min) }\end{array}$ & $\begin{array}{l}\text { Duration } \\
\text { of motor } \\
\text { blockade (min) }\end{array}$ \\
\hline Group & $96 \pm 17$ & $116 \pm 14$ \\
2. Dibucaine & $136 \pm 23$ & $147 \pm 26$ \\
3. Dibucaine + EP 2.5 $\mu \mathrm{g}$ & $193 \pm 20^{* *}$ & $204 \pm 34^{*}$ \\
\hline
\end{tabular}

* $<<0.02, * \mathrm{p}<0.01$; compared with Group 2 data (mean \pm SEM $\mathrm{n}=10$ ). tration in patients who received plain dibucaine $(0.170 \pm$ $\left.0.052 \mathrm{ng} \cdot \mathrm{ml}^{-1}\right)$ or added $\mathrm{EP}\left(0.174 \pm 0.046 \mathrm{ng} \cdot \mathrm{ml}^{-1}\right)$, but there was no statistically significant change.

Free CSF EP levels were undetectable $\left(<10 \mathrm{pg} \cdot \mathrm{ml}^{-1}\right)$ in every patient and conjugated CSF EP Icvcls were also undetectable in half of the patients, except for the data presented in Figures 1 and 2 which was obtained from the patients who were anaesthetised with EP added to dibucaine.

As seen in Figure 1 CSF free CA levels increased logarithmically, due to the addition of $\mathrm{CA}$ to the dibucaine in Group 1 patients. The mean free CSF CA level was $1,428 \mathrm{ng} \cdot \mathrm{ml}^{-1}$ in patients who received the usual dose of $\mathrm{NE}$ or EP $(<100 \mu \mathrm{g})$. It was more than 10,000 times the preanaesthetic free CA level.

Conjugated $\mathrm{CA}$ levels were also increased after drug administration (Figure 2). The free/conjugated ratio of $\mathrm{NE}$ increased to $93 \pm 20$ from $0.59 \pm 0.17$ following NE addition.

There were no significant differences with regard to patients' age and body weight between Groups 1, 2, 3 and 4 (Table I). The duration of sensory anaesthesia was significantly longer in Group 4 compared with Group 2 and Group 3 (Table II). The duration of motor blockade was significantly longer in Group 4 compared with Group 2. No differences were found in the highest dermatome blocked in Groups 2, 3 or 4 (Table I).

There were no side effects in any patients during anaesthessia.

\section{Discussion}

We have shown that small doses of NE significantly prolong the duration of sensory and motor block, compared with the effects of plain dibucaine, and are more useful than EP in the same doses for prolonging the duration of spinal anaesthesia.

Meagher et al..$^{8}$ reported that the alpha adrenoceptor stimulant phenylephrine caused a significantly greater prolongation of the time of regression of sensory anaesthesia than EP. Recently, Caldwell et al. ${ }^{9}$ also found that phenylephrine prolongs the duration of sensory anaesthesia to a greater extent than EP. In contrast, Concepcion et $a l .{ }^{10}$ reported the result of a double blind comparison of the effects of EP $(0.2 \sim 0.3 \mathrm{mg})$ and phenylephrine $(1 \sim 2$ $\mathrm{mg}$ ) on the duration of tetracaine spinal anaesthesia. Both drugs prolonged the duration of sensory and motor block compared with the effects of plain tetracaine, but no significant difference was found between the degree of prolongation caused by the vasoconstrictors. They concluded that in "equivalent" or equipotent doses $(1 \mathrm{mg} \mathrm{EP}=$ $10 \mathrm{mg}$ phenylephrine) the effect of EP and phenylephrine were not different. However, it is difficult to conclude 
which dose of phenylephrine is optimal and equipotent to EP because phenylephrine is not an endogenous CA, and there is a large difference in their potencies.

The classic explanation for the prolongation of spinal anaesthesia by $C . A$ is that alpha-adrenergic mediated vasoconstriction decreases the uptake of local anaesthetics. However, EP does not jnhibit the washout of tetracaine ${ }^{11}$ or lidocaine ${ }^{12}$ from the CSF, and neither EP nor phenylephrine added to spinal anaesthetic solutions affect the distribution of local anaesthetics within the subarachnoid space. ${ }^{13}$ Further, Bedder et al. ${ }^{3}$ reported that the a $\mathrm{aph}_{2}$ adrenoceptor stimulant clonidine is as effective as epinephrine in prolonging spinal anesthesia in dogs. The main endogenous CA in the CSF is $\mathrm{NE}$, and is increased in patients with chronic pain compared with surgical patients without pain, during spinal anaesthesia. ${ }^{5}$ Takagi et al. ${ }^{14}$ reported that noxious stimuli increase spinal levels of the NE metabolite normetanephrine in rats. These reports suggest the main mechanism of prolonging spinal anaesthesia by added vasoconstrictors may be a direct effect on the spinal nociceptive system.

In this study, we only examined the effects of $2.5 \mu \mathrm{g}$ $\mathrm{CA}$ on the duration of spinal anaesthesia in order to avoid the side effects of added CA, but CSF free NE levels increased to $10 \mathrm{ng} \cdot \mathrm{ml}^{-1}$ with use of $2.5 \mu \mathrm{g} \mathrm{NE}$. This is almost 100 times the normal CSF free NE level and is 80 times the CSF NE level of patients with chronic pain. ${ }^{5}$ The duration of spinal anaesthesia in Group 1 patients was not reported, because $2 \mathrm{ml}$ of CSF were withdrawn $3 \mathrm{~min}$ after the administration of the drug. CSF NE levels increased to $1800 \mathrm{ng} \cdot \mathrm{ml}^{-1}$, more than 10,000 times the preanaesthetic value, in patients who received $100 \mu \mathrm{g}$ of $\mathrm{NE}$ added to dibucaine. We therefore continued the study with small doses of CA's. However, we suspect that there were no significant differences between the patients receiving $2.5 \mu \mathrm{g}$ of $\mathrm{NE}$ and those receiving more than 50 $\mu \mathrm{g}$ of NE, from Group 1 data. From these data, we suggest that addition of $2.5 \mu \mathrm{g} \mathrm{NE}$ is enough to prolong the duration of spinal anaesthesia. The dose of added CA to the spinal anaesthetic solution should be severely restricted, to prevent ischaemic damage to the spinal cord caused by abnormally high levels of CSF CA during spinal anaesthesia.

\section{References}

1 Reddy SVR, Yaksh TL. Spinal noradrenergic terminal system mediates antinociseption. Brain Res 1980; 189: 391-401

2 Yaksh TL. Direct evidence that spinal serotonin and noradrenaline terminals mediate the spinal antinociceptive effects of morphine in the periaqueductal gray. Brain Res 1979; 160: 180-5

3 Bedder MD, Kozady R, Palahniak RJ et al. Clonidine prolongs canine tecracaine spinal anaesthesia. Can Anaesth Soc J 1986; 33: 591-6.

4 Kuraishi $Y$, Harada $Y$, Takagi $H$. Noradrenaline regulation of pain transmission in the spinal cord mediated by $\alpha$-adrenoceptors. Brain Res 1979; 174: 333-6.

5 Oleno T, Miyoshi Y. Yukinari T et al. Pain and noradrenaline concentration in cerebrospinal fluid. Masui 1983; 32: $183-91$

6 Anton $A H$, Sayre DF. A study of the factors affecting the aluminium oxide trihydroxyindole procedure for the analysis of catecholamincs. J Pharmacol Exp Ther 1962; 138: 360-75.

7 Bromage PR. A comparison of the hydrochloride and carbondioxide salts of lidocaine and prilocaine in epidural analgesia. Acta Anaesthesiol Scand (Suppl) 1965; 16: 55-9.

8 Meagher PR, Moore DC, DeVries JC. Phenylephrine: the most effective potentiation of tetracaine spinal anesthesia. Anesth Anal 1966; 45: 134-9.

9 Caldwell C, Nielsen C, Blatz $T$. Comparison of high-dose epinephrine and phenylephrine in spinal anesthesia with tetracaine. Anesthesiology 1985; 62: 804-7.

10 Concepcion $M$, Maddi $R$, Francis $D$, et al. Vasoconstrictors in spinal anesthesia with tetracaine: a comparison of epinephrine and phenylephrine. Anesth Analg 1984; 63 : 134-8.

11 Converse JG, Landmesser $C H$, Harmel $M H$. The concentration of pontocaine hydrochloride in the cenebrospinal fluid during spinal anesthesia and the influence of epinephrine in prolonging the sensory anesthetic effect. Anesthesiology 1954; 15: 1-6.

12 Denson DD, Bridenbaugh PO, Turner PA et al. Neural blockade and pharmacokinetics following subarachnoid lidacaine in the rhesus monkey. 1. Effect of epinephrine. Anesth Analg 1982; 61: 746-50.

13 Armstrong $7 R$, Littiewood DG, Chambers WA. Spinal anesthesia with tctracaine effect of added vasoconstrictors. Anesth Analg 1983; 62: 793-5.

14 Takgi $H_{\text {, Shiomi } H, F u k u i} K$ at al. Pain and the bulbospinal noradrenergic system: pain-induced increase in normetanephrine content in the spinal cord and its modification by morphine. Europ J Pharmacol 1979; 54: 99-107. 


\section{Résumé}

L'effet des catécholamines ajoutées la dibucaïne sur la durée de l'anesthésie rachidienne et le taux de catéchoiamines dans le liquide céphalorachidien sont étudiés. Le taux de norépinéphrine libre augmenta de $0.107 \mathrm{ng}^{-\mathrm{ml}^{-1}}$ avant l'anesthesie d $5.8 \mathrm{ng} \cdot \mathrm{ml}^{-1}$ et $1.238 \mathrm{ng} \cdot \mathrm{ml}^{-1}$ après $1 \mathrm{\mu g}$ on $100 \mu \mathrm{g} \mathrm{de}$ norépinéphrine ajouté à l'anesthésie locale. Les effets de $2.5 \mu \mathrm{g}$ de norépinéphrine ou d' épinéphrine ajouté à la dibucaine sur la durée du bloc moseur et le temps de régression sensorielle furent comparés. Les deux temps furent significativement prolongés par l'addition de norépinéphrine, de $96 \pm 17 \mathrm{~min}$ à $193 \pm 20$ min (blocage sensoriel) et de $116 \pm 14$ min à $204 \pm 34$ min (blocage moteur), mais ne furent pas altérés par l'addition d'épinéphrine. Ces données suggèrent qu' une dose de $2.5 \mu \mathrm{g} d e$ nurépinúphrine suffi pour prolonger ta durée de l'anesthésie. rachidienne et qu'elle est plus efficace qu' une même dose d'épinéphrine. 